\author{
П.Ф. Щапов ${ }^{1}$, Р.С. Томашевський ${ }^{1}$, Б.В. Ткачук ${ }^{1}$, В.М. Павлюк ${ }^{2}$ \\ ${ }^{1}$ Начіональний технічний університет «Харківський політехнічний інститут», Харків \\ ${ }^{2}$ Медицинский центр МИЛНЕР МЕДИКАЛ(Milner Medical Center), Харків
}

\title{
ІНФОРМАЦІЙНА ТЕХНОЛОГІЯ СТАТИСТИЧНОГО УПРАВЛІННЯ ПРОЦЕДУРОЮ УЛЬТРАФІЛЬТРАЦІЇ ПРИ ПРОГРАМНОМУ ГЕМОДІАЛІЗІ
}

\begin{abstract}
У статті запропоновано інформаційну технологію статистичного управління процедурою ультрафільтрачіï при програмному гемодіалізі на основі інформаиї, отриманої з сигналів біоімпедансометрії. У статті проведено аналіз літературних джерел, який показав гостру необхідність розробки системи інформаційної підтримки проиедури гемодіалізу або ї̈ автоматизаиії. Недосконалість класичних методів оцінки рівня гідратації пацієнта не дозволяє використовувати їх в якості сигналів індикації стану біологічного об'єкта в режимі реального часу. Аналітичний огляд показав, щзо найбільш підходящим сигналом, за допомогою якого можливий моніторинг стану пацієнта, є сигнал біоімпедансометріі. Метою роботи була розробка інформаційної технології моніторингу стану пацієнта і статистичного управління процедурою ультрафільтрачії на основі сигналів біоімпедансометріі. Для аналізу таких сигналів був обраний коваріаційний аналіз, так як він дозволяє оцінити глобальні та локальні тренди сигналу з урахуванням його нестаціонарності, а також оцінити значимість зміни циих трендів. На тренди класичного коваріаційного розкладання, в роботі був запропонований модифікований коваріаційний метод аналізу, який дозволяє враховувати відносну зміну трендів біоімпедансних сигналів на декількох частотах, $i$, тим самим, зменшуючи суму випадкового залишку. Такий підхід дозволяє, збільшуючи чутливість методу до динамічних змін, отримати додатковий інформативний параметр. Експериментальні дослідження на пацієнтах, які перебувають на процедурі програмного гемодіалізу, показав ефективність запропонованого методу. Адекватність отриманих статистичних рішень повністю підтвердилася результатами контрольного дослідження - вимірювання рівня гематокриту.
\end{abstract}

Ключові слова: програмний гемодіаліз, ультрафільтрація, інтерстиціальна рідина, біоімпедансометрія, модель Фрікке-Морзе, коваріаџійний аналіз, оптимізаџія, середній ризик, статистичне управління.

\section{Вступ}

Постановка проблеми. На сьогоднішній день, в лікувальних установах світу встановлена велика кількість апаратів для гемодіалізу. В Україні, крім спеціалізованих діалізних центрів, апарати є в відділеннях реанімації та інтенсивної терапії основних міських лікарень. Лікування програмним гемодіалізом в Україні, станом на 2016 рік проходить понад 5,5 тисяч осіб з хронічною нирковою недостатністю.

Але не дивлячись на відчутну затребуваність даного методу, існує ряд ускладнень під час гемодіалізу. При досягненні пацієнтом стану нормогідратаціі, швидкість, з якою заповнюється судинне русло 3 навколишніх тканин, зменшується. У деяких хворих збільшення ваги в междіалізний період невелика або зовсім відсутній. Спроби прибрати рідина у пацієнта при відсутності її надлишку ведуть до гіпотензії як на діалізі, так і після нього, і поєднуються 3 судомами, запамороченням і загальним нездужанням. 3 іншого боку, іноді персонал занадто обережний в спробах видалити рідину у хворих, схильних до гіпотензії, і це веде до перевантаження рідиною i гіпертензії $[1,6]$.

На даний момент, не існує адекватних методик та апаратних засобів для визначення стану нормогідратаціі при програмному гемодіалізі. Обсяг рідини необхідний для скачування, пацієнту озвучує лікар при огляді, тільки виходячи зі свого досвіду і суб'єктивних відчуттів пацієнта [1-3].

\section{Аналіз літератури}

Гемодіаліз - це процедура апаратної, екстракорпоральної очистки крові, яка представляє собою тривалу, циклічну циркуляцію крові через спеціальний фільтр. Під час гемодіалізу з крові видаляються шлаки, продукти обміну речовин, а також надлишки рідини (ультрафильтрат), накопичені за час, який нирки нормально не функціонували. Забір і повернення крові здійснюється через спеціалізований артеріо-венозний доступ (фістулу) або катетер. Середня тривалість процедури становить чотири години, періодичність - три рази в тиждень [2-3].

Принцип дій апаратів «штучна нирка» різних виробників приблизно однаковий, різниця складаються лише в дизайні, як обладнання та витратних матеріалів, а також наявності додаткових опцій [2].

Існує кілька груп показників, визначення яких дозволяє знизити ризик виникнення ускладнень i підвищити терапевтичний ефект процедури: показники електролітного складу внутрішньо- і позаклітинної рідини, показники гемодинаміки, показники функціонально пов'язані 3 рідинними секторами організму [1-3, 10].

Під контролем гемодинаміки розуміється контроль кровонаповнення судин, контроль артеріально- 
го тиску, пульсу та інші. Контроль тиску, в даний час, проводиться ручним або осцилометричним методом, в певний час в ході процедури. Блок для вимірювання артеріального тиску вбудований в деяких апаратах «штучна нирка», також він дозволяє контролювати і пульс пацієнта $[3,10]$.

Для контролю кровонаповнення використовуються ультразвукові датчики, які кріпляться на магістраль 3 кров'ю. По проходженню ультразвукового сигналу визначають щільність крові, обчислюючи гематокрит, гемоглобін, зміна обсягу крові щодо початку процедури, тим самим, не даючи під час скачування рідини з крові, переступити поріг критичного іiі згущення. Для корекції вимірювань, вироблених таким способом необхідна температурна корекція, так як щільність крові в значній мірі залежить від їі температури $[3,6]$. Вартість подібного обладнання надзвичайно висока. Контроль зміни обсягів водних середовищ організму під час процедури ПГД в світовій практиці не використовується, так як на сьогоднішній день відсутні відповідні методики i апаратні засоби. Значення даних обсягів лікар визначає виходячи з власних знань і досвіду, а також суб'єктивних відчуттів пацієнта.

Вся рідина організму поділяється на внутрішньоклітинну (ВКР) і позаклітинну рідини (ПЗР) (рис. 1). У поняття ПЗР входять всі рідкі фракції організму, не включені у клітинні мембрани: внутрішньосудинна рідина (BР) - плазматична рідина i лімфа, інтерстиціальна рідина (IP), а також трансцелюлярна рідина (ТР), яка міститься в спеціалізованих порожнинах (спинномозкова, перикардіальна, плевральна, синовіальна, внутрішньоочна, травні соки) [4]. Об'єм ПЗР ( $\left.\mathrm{V}_{\text {ПзР }}\right)$ дорівнює сумі об'ємів інтерстиціальної $\left(\mathrm{V}_{\mathrm{IP}}\right)$, внутрішньосудинної $\left(\mathrm{V}_{\mathrm{BP}}\right)$ i трансцеллюлярної ( $\left.\mathrm{V}_{\text {Тц }}\right)$ рідин

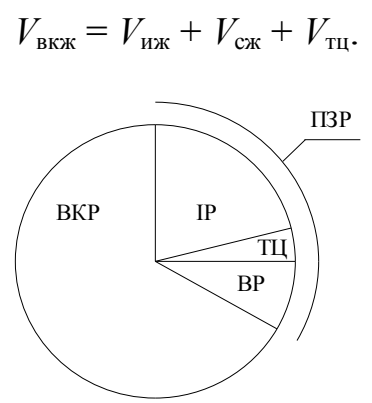

Рис. 1. Розподіл рідин в організмі

Надлишки рідини в організмі представлені в основному ПЗР, яка розташовується в судинному руслі, органах системи кровообігу і скелетної мускулатури [11]. При видаленні рідини з судинного русла відбувається перерозподіл водноелектролітного складу рухомої частини ПЗР. При цьому надлиш-

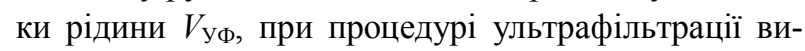
даляється $з$ судинного русла, а воно у свою чергу, заповнюється рідиною 3 тканини (або інтерстиціа- льного сектора), при цьому обсяг клітинної рідини залишається практично незмінним $[4,10]$.

У разі якщо швидкість ультрафільтрації більше швидкості заповнення судинного русла, то через деякий час, обсяг судинної рідини зменшиться до критичного, а це призведе до падіння артеріального тиску. Для недопущення подібної ситуації, необхідно постійно контролювати артеріальний тиск, а, отже, і обсяг судинної рідини доступний для скачування і кількість надлишків рідини, які містяться в інтерстиціальному просторі $[2,3,10]$.

\section{Метод біоімпедансометрії для інформаційної підтримки процедури ультрафільтрації}

Біоімпедансний метод заснований на вимірюванні імпедансу $Z$ всього тіла або окремих сегментів тіла $з$ використанням спеціальних приладів - біоімпедансних аналізаторів. Електричний імпеданс біологічних тканин має два компоненти: активний $R \mathrm{i}$ реактивний опір $X$, пов'язані співвідношенням:

$$
\mathrm{Z}^{2}=\mathrm{R}^{2}+\mathrm{X}^{2} \text {. }
$$

Складовою активного опору $\mathrm{R}$ в біологічному об'єкті є рідини (ВКР і ПЗР), що мають іонний механізм провідності. Складовою реактивного опору $\mathrm{X}$ $\epsilon$ клітинні мембрани. Біоімпедансний аналіз складу тіла полягає в оцінці кількості рідини в біооб'єкти, так як саме рідке середовище створює активну складову провідності [5-9].

Електричний струм може протікати, огинаючи клітини і через клітини, як показано на рис. 2, а. Межі клітин утворені мембранами, які за своїми електричними властивостями $є$ конденсаторами з залежною від частоти змінного струму ємністю $[5-8,17]$.

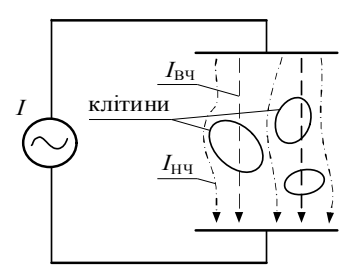

a

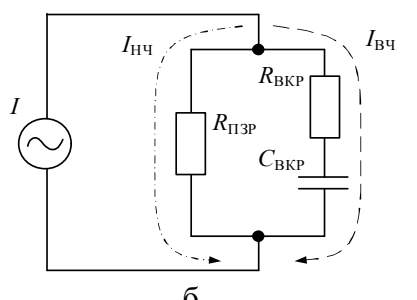

6
Рис. 2. Схема проходження струмів (а)

і загальноприйнята еквівалентна схема (б)

одиничного відрізок тканини при БІМ

Еквівалентна схема біооб'єкту, звана також моделлю Фрике - Морзе, (рис. 2, б) містить опір позаклітинної рідини $\mathrm{R}_{\text {пзр}}$, опір клітинної рідини $\mathrm{R}_{\mathrm{BKP}} \mathrm{i}$ ємність мембран $\mathrm{C}_{\mathrm{M}}$. Щоб визначити обсяг ВКЖ, необхідно вимірювати імпеданс на постійному струмі, так як в цьому випадку клітинні мембрани залишаються непроникними, і внутрішньоклітинна рідина не впливає на результат вимірювання. Для визначення загальної рідини організму, необхідно вимірювати імпеданс на нескінченно великій частоті, коли струм проходить через клітку. 
Уточнена схема для БІМ процесів гідратації в організмі пацієнта на ПГД, що була представлена у ряді робіт $[18,19]$, матиме вигляд, як на рис 3 . Ця схему враховує можливості визначення і моніторування гемодинамічних параметрів при процедурі ультрафільтрації, та включає окрему гілку, що характеризує формені елементи крові (ФЕК). У цій схемі $\mathrm{R}_{\text {ФЕК }}$ - відповідає обсягу рідини в ФЕК, $\mathrm{R}_{\text {КР }}$ - обсягом рідини у всіх інших клітинах (за винятком ФЕК), $\mathrm{C}_{\text {ФЕК }}$ - ємність мембран клітин формених елементів крові, $\mathrm{C}_{\mathrm{KP}}$ - ємність мембран всіх клітин організму (за винятком клітин формених елементів). На рис. 4 наведені три складові результатів біоімпедансометрії (на частотах 20, 100 та 500 кГц), що буди отримані впродовж стандартної процедури УФ. Дослідження, проведені у роботах $[17,18]$ дозволили умовно розділити процедуру УФ на три характерні фази: I фаза - зниження обсягу судинного русла, запуск механізму компенсації з позаклітинної рідини; II фаза - видалення позаклітинної рідини організму без зниження рівня судинного русла; III фаза - зупинка транспорту між судинним і інтерстиціальним руслом, видалення рідини проводиться тільки $з$ судин. Перехід організму в критичний стан.

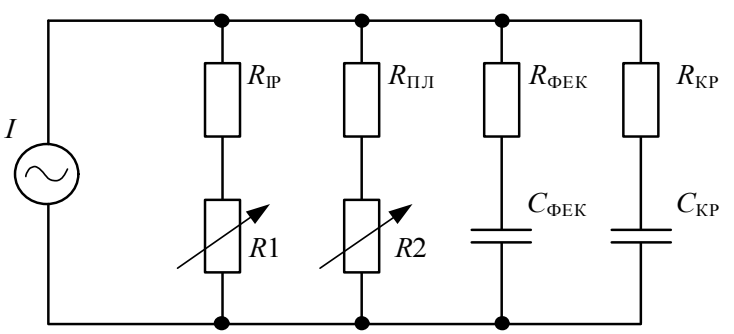

Рис. 3. Розширена еквівалентна електрична схема для БІМ процесів гідратації організму при процедурі ПГД

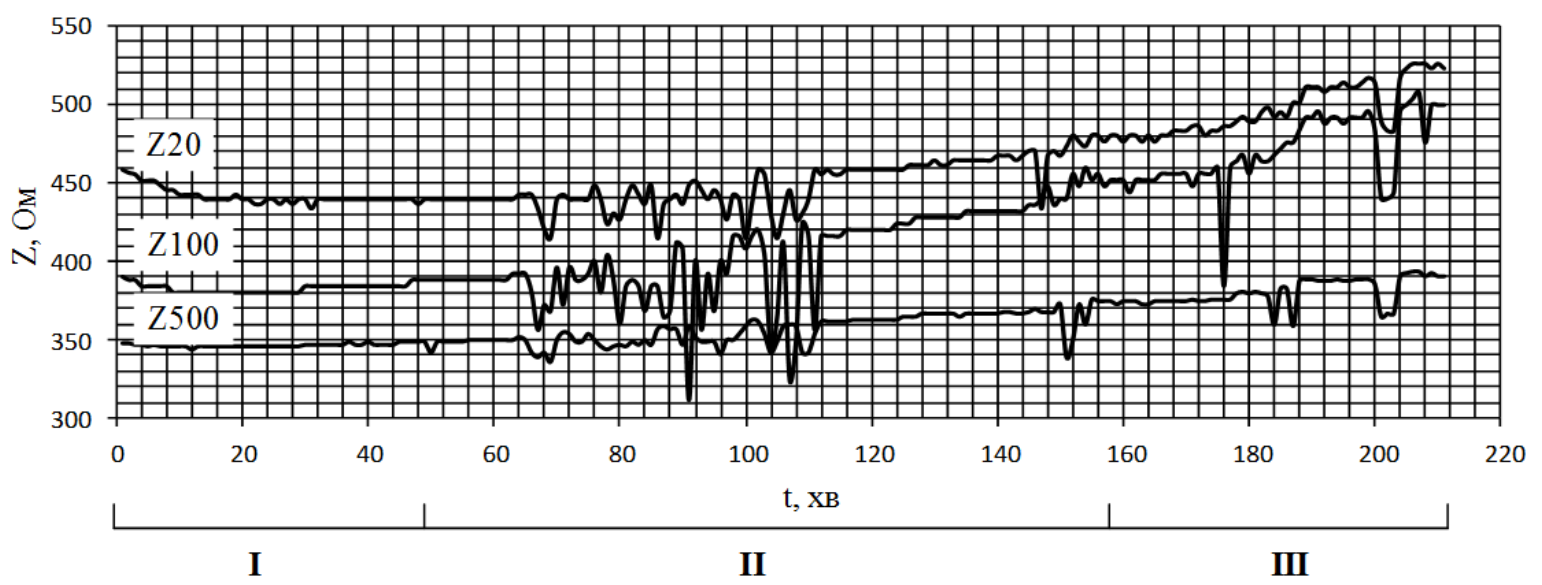

Рис. 4. Результати біоімпедансометрії та трьох стандартних частотах $(20,100$ та 500 кГц) впродовж типової процедури УФ

Також у попередніх роботах було запропоновано використання статистичних методів аналізу даних, отриманих за допомогою БІМ під час процедури УФ, для підтримки прийняття рішень лікарем про поточний рівень гідратації пацієнта, з урахуванням його вітальних ознак. Для цього було застосовано класичний коваріаційний аналіз результатів вимірювання БІМсигналу, причому первинні дані були підготовлені двома методиками: сканування (ковзаюче вікно з фіксованою кількістю відліків) та накопичення (в аналіз включені усі дані, кількість яких зростає впродовж процедури УФ). У результаті досліджень було встановлено F-статистики $\mathrm{F}_{0}, \mathrm{~F}_{\mathrm{WG}}, \mathrm{F}_{\mathrm{G}}, \mathrm{F}_{\mathrm{W}}$ можуть бути використані у якості інформативних параметрів активного моніторингу стану пацієнта та можуть дозволити визначення переходу з однієї фази процедури УФ на інший. Однак, окреме використання в якості інформативних параметрів F-статистик БІМ-сигналів на різних частотах не дозволяс однозначно судити про рівень гідратації пацієнта, так як не враховує взаємний вплив різних складових БІМ, і може бути використана лише для ідентифікації зміни тренда кожної з них. Таким чином, необхідна розробка методу аналізу результатів вимірювання БІМ-сигналу на основі коваріаційного розкладання, що враховує взаємне змін трендів таких сигналів на різних частотах, і дозволяє повністю використовувати інформаційні властивості БІМ-моніторингу при проведенні процедури УФ.

Мета роботи: розробка інформаційної технології модифікованого коваріаційного аналізу для статистичного управління і активного моніторингу параметрів процедури ультрафільтрації з використанням неінвазійних сигналів біоінпедансометріi.

\section{Метод модифікованого коваріаційного аналізу}

Удосконалення класичної моделі коваріаційного аналізу можливо, якщо використовувати систему багаторазових спостережень (вимірювань) значень випадкової величини Y, що залежить від фактору часу Х. Особливість такої моделі - це можливість тривимірного представлення величини Y і двовимірного представлення величини $\mathrm{X}$, представлених відповідно реалізаціями $\mathrm{y}_{\mathrm{tij}} \mathrm{i} \mathrm{x}_{\mathrm{t}}$, де $\mathrm{t}$ - номер частинної регресії (групи), i - номер внутрішньогрупового вимірювання, j - номер багаторазового внутрішньогрупового 
вимірювання. Розглянемо модифіковану коваріаційну модель двовимірних спостережень при односторонній класифікації, коли для будь-якого $з$ фіксованих значень аргументу $\mathrm{x}_{\mathrm{ti}}$ мають місце $\mathrm{n}_{\mathrm{ti}}$ багаторазових спостережень $\mathrm{Y}_{\mathrm{tij}}$ випадкової функції $\mathrm{Y}$

$$
\mathrm{Y}_{\mathrm{tij}}=\mathrm{a}_{\mathrm{t}}+\mathrm{bx}_{\mathrm{ti}}+\mathrm{e}_{\mathrm{tij}}
$$

де $\mathrm{t}=\overline{1, \mathrm{r}} ; \mathrm{i}=\overline{1, \mathrm{c}_{\mathrm{t}}} ; \mathrm{j}=\overline{1, \mathrm{n}_{\mathrm{ti}}} ; \mathrm{r}$ - кількість послідовних частинних регресій, $c_{t}-$ кількість внутрішньогрупових незалежних багаторазових вимірювань для t-й регресії.

Таблиця 1

Результати двофакторного коваріаційного експерименту

\begin{tabular}{|c|c|c|c|c|c|}
\hline $\begin{array}{l}\text { № групи рез. } \\
\text { вимірювання }\end{array}$ & \multicolumn{5}{|c|}{$\begin{array}{c}\text { Значення результатів двофакторного } \\
\text { експерименту з багаторазовими вимірами }\end{array}$} \\
\hline \multirow[t]{2}{*}{1} & $\left\{\mathrm{Y}_{11 \mathrm{j}}\right\}_{1}^{\mathrm{n}_{11}}$ & $\cdots$ & $\left\{\mathrm{Y}_{1 \mathrm{ij}}\right\}_{1}^{\mathrm{n}_{1 \mathrm{i}}}$ & $\cdots$ & $\left\{\mathrm{Y}_{1 \mathrm{c}_{1} \mathrm{j}}\right\}_{1}^{\mathrm{n}_{1 \mathrm{c}_{1}}}$ \\
\hline & $\mathrm{x}_{11}$ & $\ldots$ & $\mathrm{x}_{1 \mathrm{i}}$ & $\ldots$ & $\mathrm{x}_{1 \mathrm{c}_{1}}$ \\
\hline$\ldots$ & \multicolumn{5}{|c|}{$\ldots$} \\
\hline \multirow{2}{*}{$\mathrm{t}$} & $\left\{Y_{t 1 j}\right\}_{1}^{n_{t 1}}$ & $\cdots$ & $\left\{Y_{\mathrm{tij}}\right\}_{1}^{\mathrm{n}_{\mathrm{ti}}}$ & $\cdots$ & $\left\{Y_{t_{t}}\right\}_{1}^{n_{t c_{t}}}$ \\
\hline & $x_{t 1}$ & $\ldots$ & $\mathrm{x}_{\mathrm{ti}}$ & $\ldots$ & $x_{t c_{t}}$ \\
\hline$\ldots$ & \multicolumn{5}{|c|}{$\ldots$} \\
\hline \multirow{2}{*}{$\mathrm{r}$} & $\left\{\mathrm{Y}_{\mathrm{r} 1 \mathrm{j}}\right\}_{1}^{\mathrm{n}_{\mathrm{r} 1}}$ & $\cdots$ & $\left\{\mathrm{Y}_{\mathrm{rij}}\right\}_{1}^{\mathrm{n}_{\mathrm{ri}}}$ & $\cdots$ & $\left\{\mathrm{Y}_{\mathrm{rc}_{\mathrm{r}}}\right\}_{1}^{\mathrm{n}_{\mathrm{rc}_{\mathrm{r}}}}$ \\
\hline & $\mathrm{x}_{\mathrm{r} 1}$ & $\ldots$ & $\mathrm{x}_{\mathrm{ri}}$ & $\ldots$ & $\mathrm{x}_{\mathrm{rc}_{\mathrm{r}}}$ \\
\hline
\end{tabular}

Коваріаційна модель (3) дозволяє збільшити кількість членів нового модифікованого коваріаційного розкладання на одиницю

$$
\mathrm{S}=\mathrm{S}_{0}^{\mathrm{M}}+\mathrm{S}_{\mathrm{WG}}^{\mathrm{M}}+\mathrm{S}_{\mathrm{G}}^{\mathrm{M}}+\mathrm{S}_{\mathrm{W}}^{\mathrm{M}}+\mathrm{S}_{\mathrm{R}}^{\mathrm{M}}+\mathrm{S}_{\mathrm{e}}
$$

При незмінності ймовірнісної моделі об'єкта дослідження (за однакової кількості математичних очікувань середнього квадрата повних сум $\mathrm{S}$ та $\mathrm{S}^{\mathrm{M}}$ ) середній квадрат $\overline{\mathrm{S}}_{\mathrm{R}}$ залишкової суми $\mathrm{S}_{\mathrm{R}}$ буде більше середнього квадрата $\overline{\mathrm{S}}_{\mathrm{e}}$ залишкової суми $\mathrm{S}_{\mathrm{e}}$.

$$
\overline{\mathrm{S}}_{\mathrm{e}}<\overline{\mathrm{S}}_{\mathrm{R}}
$$

Нерівність (5) вказує на більш високу чутливість (меншу залишкову дисперсію) модифікованого коваріаційного розкладання (4).

Введемо ряд умовних позначень.

$$
\left\{\begin{array}{l}
\mathrm{W}_{\mathrm{t}}=\sum_{\mathrm{i}=1}^{\mathrm{c}_{\mathrm{t}}} \mathrm{n}_{\mathrm{ti}}\left(\mathrm{x}_{\mathrm{ti}}-\overline{\mathrm{X}}\right)^{2} ; \mathrm{V}_{\mathrm{t}}=\sum_{\mathrm{i}=1}^{\mathrm{c}_{\mathrm{t}}} \mathrm{n}_{\mathrm{ti}} \\
\mathrm{W}_{\mathrm{m}}=\sum_{\mathrm{t}=1}^{\mathrm{r}} \mathrm{W}_{\mathrm{t}}=\sum_{\mathrm{t}=1}^{\mathrm{r}} \mathrm{V}_{\mathrm{t}}\left(\overline{\mathrm{X}}_{\mathrm{t}}-\overline{\mathrm{X}}\right)^{2} ;
\end{array}\right.
$$

$\mathrm{B}_{\mathrm{c}}=\mathrm{W}_{\mathrm{c}}^{-1} \sum_{\mathrm{t}=1}^{\mathrm{r}} \mathrm{W}_{\mathrm{t}} \cdot \mathrm{B}_{\mathrm{t}}$;

$\left\{\mathrm{B}_{\mathrm{m}}=\sum_{\mathrm{t}=1}^{\mathrm{r}} \mathrm{V}_{\mathrm{t}}\left(\overline{\mathrm{X}}_{\mathrm{t}}-\overline{\mathrm{X}}\right)\left(\overline{\mathrm{Y}}_{\mathrm{t}}-\overline{\mathrm{Y}}\right) / \sum_{\mathrm{t}=1}^{\mathrm{r}} \mathrm{V}_{\mathrm{t}}\left(\overline{\mathrm{X}}_{\mathrm{t}}-\overline{\mathrm{X}}\right)^{2} ;(7)\right.$ $\mathrm{B}_{0}=\mathrm{W}_{0}^{-1}\left(\mathrm{~W}_{\mathrm{c}} \mathrm{B}_{\mathrm{c}}+\mathrm{W}_{\mathrm{m}} \mathrm{B}_{\mathrm{m}}\right)$, де $\mathrm{W}_{0}=\mathrm{W}_{\mathrm{c}}+\mathrm{W}_{\mathrm{m}}$;

$$
\left\{\begin{array}{l}
\overline{\mathrm{Y}}=\mathrm{N}^{-1} \sum_{\mathrm{t}=1}^{\mathrm{r}} \sum_{\mathrm{i}=1}^{\mathrm{c}_{\mathrm{t}}} \sum_{\mathrm{j}=1}^{\mathrm{n}_{\mathrm{ti}}} \mathrm{Y}_{\mathrm{tij}}, \text { де } \mathrm{N}=\sum_{\mathrm{t}=1}^{\mathrm{r}} \sum_{\mathrm{i}=1}^{\mathrm{c}_{\mathrm{t}}} \mathrm{n}_{\mathrm{ti}} ; \\
\overline{\mathrm{Y}}_{\mathrm{t}}=\mathrm{V}_{\mathrm{t}}^{-1} \sum_{\mathrm{t}=1}^{\mathrm{c}_{\mathrm{t}}} \sum_{\mathrm{i}=1}^{\mathrm{n}_{\mathrm{ti}}} \mathrm{Y}_{\mathrm{ti}} ; \quad \overline{\mathrm{Y}}_{\mathrm{ti}}=\mathrm{n}_{\mathrm{ti}}^{-1} \sum_{\mathrm{j}=1}^{\mathrm{n}_{\mathrm{ti}}} \mathrm{Y}_{\mathrm{ti}} ; \\
\overline{\mathrm{X}}=\mathrm{N}^{-1} \sum_{\mathrm{t}=1}^{\mathrm{r}} \sum_{\mathrm{i}=1}^{\mathrm{c}_{\mathrm{t}}} \mathrm{n}_{\mathrm{ti}} \cdot \mathrm{x}_{\mathrm{ti}} ; \quad \overline{\mathrm{X}}_{\mathrm{t}}=\mathrm{V}_{\mathrm{t}}^{-1} \sum_{\mathrm{i}=1}^{\mathrm{c}_{\mathrm{t}}} \mathrm{n}_{\mathrm{ti}} \cdot \mathrm{x}_{\mathrm{ti}} ;
\end{array}\right.
$$

У табл. 2 представлені результати модифікованого коваріаційного розкладання i, відповідні їм, нормативні критеріальні F-статистики (враховують, паралельно, варіанти рівності всередині групових, $\mathrm{C}_{\mathrm{t}}=\mathrm{C}$, i багатократних, $\mathrm{n}_{\mathrm{ti}}=\mathrm{n}$, вимірювань; $\mathrm{t}=\overline{1, \mathrm{r}}$; $\mathrm{i}=\overline{1, \mathrm{c}})$. В цьому випадку

$$
\mathrm{N}=\mathrm{rcn} \text {. }
$$

Табл. 2 дозволяє уточнити коваріаційну модель (3) у вигляді моделі відхилення результату вимірювання від загальної середньої

$$
\begin{gathered}
\mathrm{Y}_{\mathrm{tij}}-\overline{\mathrm{Y}}=\mathrm{B}_{0}\left(\mathrm{x}_{\mathrm{tij}}-\overline{\mathrm{X}}\right)+\left(\mathrm{B}_{\mathrm{c}}-\mathrm{B}_{\mathrm{m}}\right)\left(\overline{\mathrm{X}}_{\mathrm{t}}-\overline{\mathrm{X}}\right)+ \\
+\phi_{\mathrm{t}}+\left(\mathrm{B}_{\mathrm{t}}-\mathrm{B}_{\mathrm{c}}\right)\left(\overline{\mathrm{X}}_{\mathrm{t}}-\overline{\mathrm{X}}\right)+\mathrm{S}_{\mathrm{ti}}+\mathrm{e}_{\mathrm{tij}} .
\end{gathered}
$$

Таблиця 2

Результати модифікованого коваріаційного розкладання

\begin{tabular}{|c|c|c|c|}
\hline Сума квадратів відхилень & $\begin{array}{c}\text { Кількість } \\
\text { ступенів свободи }\end{array}$ & $\begin{array}{c}\text { Середній квадрат } \\
\text { відхилень }\end{array}$ & $\begin{array}{c}\text { Критеріальна } \\
\text { F-статистика }\end{array}$ \\
\hline $\mathrm{S}_{0}^{\mathrm{M}}=\mathrm{W}_{0} \mathrm{~B}_{0}^{2}$ & 1 & $\overline{\mathrm{S}}_{0}=\mathrm{S}_{0}^{\mathrm{M}}$ & $\mathrm{F}_{0}=\overline{\mathrm{S}} / \mathrm{S}_{\mathrm{e}}$ \\
\hline $\mathrm{S}_{\mathrm{WG}}^{\mathrm{M}}=\frac{\mathrm{W}_{\mathrm{c}} \mathrm{W}_{\mathrm{m}}}{\mathrm{W}_{0}}\left(\mathrm{~B}_{\mathrm{c}}-\mathrm{B}_{\mathrm{m}}\right)^{2}$ & 1 & $\overline{\mathrm{S}}_{\mathrm{WG}}=\mathrm{S}_{\mathrm{WG}}^{\mathrm{M}}$ & $\mathrm{F}_{\mathrm{WG}}=\frac{\overline{\mathrm{S}}_{\mathrm{WG}}}{\mathrm{S}_{\mathrm{e}}}$ \\
\hline $\mathrm{S}_{\mathrm{G}}^{\mathrm{M}}=\sum_{\mathrm{t}=1}^{\mathrm{r}} \mathrm{V}_{\mathrm{t}}\left[\overline{\mathrm{Y}}_{\mathrm{t}}-\overline{\mathrm{Y}}-\mathrm{B}_{\mathrm{m}}\left(\overline{\mathrm{X}}_{\mathrm{t}}-\overline{\mathrm{X}}\right)\right]^{2}$ & $\mathrm{r}-2$ & $\overline{\mathrm{S}}_{\mathrm{G}}=\frac{\mathrm{S}_{\mathrm{G}}^{\mathrm{M}}}{\mathrm{r}-2}$ & $\mathrm{~F}_{\mathrm{G}}=\frac{\overline{\mathrm{S}}_{\mathrm{G}}}{\mathrm{S}_{\mathrm{e}}}$ \\
\hline $\mathrm{S}_{\mathrm{W}}^{\mathrm{M}}=\sum_{\mathrm{t}=1}^{\mathrm{r}} \mathrm{W}_{\mathrm{t}}\left(\mathrm{B}_{\mathrm{t}}-\mathrm{B}_{\mathrm{c}}\right)^{2}$ & $\mathrm{r}-1$ & $\overline{\mathrm{S}}_{\mathrm{W}}=\frac{\mathrm{S}_{\mathrm{W}}^{\mathrm{M}}}{\mathrm{r}-1}$ & $\mathrm{~F}_{\mathrm{W}}=\frac{\overline{\mathrm{S}}_{\mathrm{W}}}{\mathrm{S}_{\mathrm{e}}}$ \\
\hline $\mathrm{S}_{\mathrm{R}}^{\mathrm{M}}=\sum_{\mathrm{t}=1 \mathrm{i}=1}^{\mathrm{r}} \sum_{\mathrm{i}}^{\mathrm{c}_{\mathrm{t}}} \mathrm{n}_{\mathrm{ti}}\left[\overline{\mathrm{Y}}_{\mathrm{ti}}-\overline{\mathrm{Y}}_{\mathrm{t}}-\mathrm{B}_{\mathrm{t}}\left(\mathrm{x}_{\mathrm{ti}}-\overline{\mathrm{X}}_{\mathrm{t}}\right)\right]$ & $\sum_{\mathrm{t}=1}^{\mathrm{r}} \mathrm{c}_{\mathrm{t}}-2 \mathrm{r}=\mathrm{r}(\mathrm{c}-2)$ & $\overline{\mathrm{S}}_{\mathrm{R}}=\frac{\mathrm{S}_{\mathrm{R}}^{\mathrm{M}}}{\mathrm{r}(\mathrm{c}-2)}$ & $\mathrm{F}_{\mathrm{R}}=\frac{\overline{\mathrm{S}}_{\mathrm{R}}}{\mathrm{S}_{\mathrm{e}}}$ \\
\hline $\mathrm{S}_{\mathrm{e}}=\sum_{\mathrm{t}=1}^{\mathrm{r}} \sum_{\mathrm{i}=1}^{\mathrm{c}_{\mathrm{t}}} \sum_{\mathrm{j}=1}^{\mathrm{n}_{\mathrm{ti}}}\left(\mathrm{Y}_{\mathrm{tij}}-\overline{\mathrm{Y}}_{\mathrm{ti}}\right)^{2}$ & $\mathrm{~N}-\sum_{\mathrm{t}=1}^{\mathrm{r}} \mathrm{c}_{\mathrm{t}}=\mathrm{rc}(\mathrm{n}-1)$ & $\overline{\mathrm{S}}_{\mathrm{e}}=\frac{\mathrm{S}_{\mathrm{e}}}{\mathrm{rc}(\mathrm{n}-1)}$ & - \\
\hline $\mathrm{S}=\sum_{\mathrm{t}=1}^{\mathrm{r}} \sum_{\mathrm{i}=1}^{\mathrm{c}_{\mathrm{t}}} \sum_{\mathrm{j}=1}^{\mathrm{n}_{\mathrm{i}}}\left(\mathrm{Y}_{\mathrm{tij}}-\overline{\mathrm{Y}}\right)^{2}$ & $\mathrm{~N}-1$ & $\overline{\mathrm{S}}=\frac{\mathrm{S}}{\mathrm{N}-1}$ & - \\
\hline
\end{tabular}


Послідовність доданків у правій частині рівняння (10), це послідовність незалежних випадкових відхилень, відповідних послідовності членів розкладання (4). Математичне сподівання всіх відхилень рівняння (10) дорівнюють нулю. залишкова дисперсія $\sigma_{\mathrm{e}}^{2}$ послідовного відхилення $\mathrm{e}_{\mathrm{tij}}$ - постійна, характеризуючи статистичну невизначеність модифікованої моделі (3). Природно припустити, виходячи 3 нерівності (5), що

$$
\sigma_{\mathrm{e}}^{2}<\sigma_{\mathrm{R}}^{2}
$$

3 табл. 2 випливає, що при плануванні коваріаційного експерименту, вимоги до мінімальних обсягів групових (c) багатократних (n) вимірювань визначаються умовами

$$
\mathrm{c} \geq 3 ; \quad \mathrm{n} \geq 2,
$$

при цьому мінімальне кількість (r) залишкових регресій $\mathrm{r} \geq 3[13,15]$.

Результати вимірювань БІМ-сигналу на різних частотах при процедурі УФ можуть бути розглянуті як результати двофакторного експерименту з багаторазовими вимірами. 3 використанням виразів коваріаційного модифікованого розкладання (табл. 2) був проведений аналіз БІМ-сигналу (рис. 3), виміряного в перебігу типової процедури УФ, і визначені значення F-статистик для двох методик підготовки первинних даних: сканування і накопичення. На рисунку 5 представлені результати аналізу (для статистики $\mathrm{F}_{0}$ ) результатів вимірювання БІМ-сигналу модифікованим коваріаційним методом.

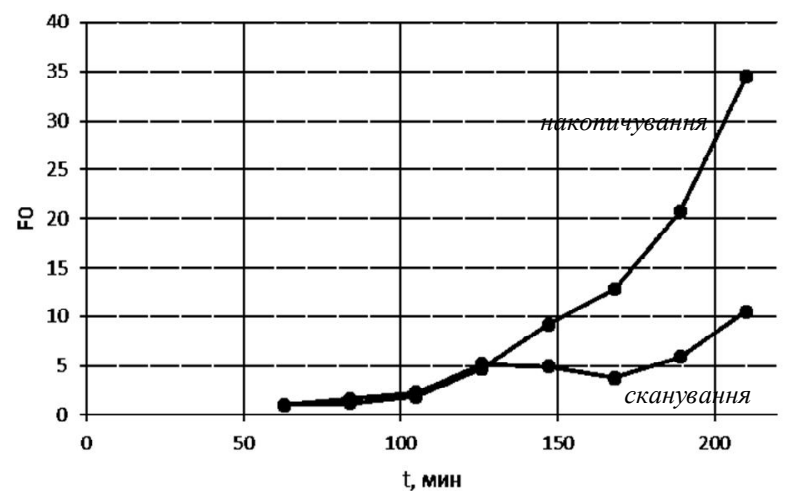

Рис. 5. Результати аналізу БІМ-сигналу модифікованим коваріаційним методом під час стандартної процедури УФ (статистика $\mathrm{F}_{0}$ ) для процедур сканування та накопичування

Аналіз отриманих результатів дозволяє зробити висновок про те, що F-статистика, отримана в модифікованим коваріаційного аналізу (методикою як накопичення, так і сканування) може бути використаний в якості інформативного параметра моніторингу процедури УФ. Результати такого аналізу враховують групове вплив трендових змін БІМ-сигналу на різних частотах і мають знижений, в порівнянні 3 класичним коваріаційного аналізу, вплив випадкової шумовий складової. Більш того, даний метод дозволяє, розглядаючи процедуру УФ, як фактор впливає на стан біологічного об'єкта, використовувати стандартний тест на значимість такого впливу. Згідно табл. 2, критичне значення F-статистики для суми $\mathrm{S}_{0}^{\mathrm{M}}$ і рівні значущості $\alpha=0,05$ буде дорівнювати $\mathrm{F}_{1,120,0.05}=3.92$. Таким чином, на ділянках зі значеннями стає можливим ідентифікувати ділянку III, на якому вплив фактора на об'єкт стає значущим, що повністю збігається з даними виміру гематокриту. Слід звернути увагу на значну зміну характеру 2 кривих F-статистики одна відносно іншої у точці переходу процедури з II фази у III фазу.

\section{Комбіновані інформативні показники на основі модифікованого коваріаційного аналізу}

3 рівняння (10) випливає, що за геометричну нелінійність математичного сподівання прогресу $\mathrm{Y}=\mathrm{F}(\mathrm{X})$, як часового ряду $[14,15]$, відповідають відхилення $\phi_{\mathrm{t}},\left(\mathrm{B}_{\mathrm{t}}-\mathrm{B}_{\mathrm{c}}\right)\left(\overline{\mathrm{X}}_{\mathrm{t}}-\overline{\mathrm{X}}\right)$ и $\delta_{\mathrm{ti}}$, відповідні сумами $\mathrm{S}_{\mathrm{G}}^{\mathrm{M}}, \mathrm{S}_{\mathrm{W}}^{\mathrm{M}}$ и $\mathrm{S}_{\mathrm{R}}^{\mathrm{M}}$. Перевірка основної гіпотези. $\mathrm{H}_{0}: \phi_{\mathrm{t}}=0 ; \mathrm{B}_{\mathrm{t}}=\mathrm{B}_{\mathrm{c}} ; \delta_{\mathrm{ti}}=0$ для усіх $\mathrm{t}=\overline{1, \mathrm{r}}$ та $\mathrm{t}=\overline{1, \mathrm{c}}$ (нелінійність відсутня), може здійснюватися за допомогою комплексної критеріальної статистики

$$
\mathrm{F}_{(\mathrm{rc}-3) ; \mathrm{rc}(\mathrm{n}-1)}^{(0)}=\left(\mathrm{S}_{\mathrm{G}}^{\mathrm{M}}+\mathrm{S}_{\mathrm{W}}^{\mathrm{M}}+\mathrm{S}_{\mathrm{R}}^{\mathrm{M}}\right) /\left((\mathrm{rc}-3) \cdot \overline{\mathrm{S}}_{\mathrm{e}}\right),
$$

що має rc-3 та rc(n-1) ступенів свободи.

Вираз (13) можна переписати в іншому вигляді

$$
\mathrm{F}_{(\mathrm{rc}-3) ; \mathrm{rc}(\mathrm{n}-1)}^{(0)}=\mathrm{F}_{\mathrm{G}}\left(\frac{\mathrm{r}-2}{\mathrm{rc}-3}\right)+\mathrm{F}_{\mathrm{W}}\left(\frac{\mathrm{r}-1}{\mathrm{rc}-3}\right)+\mathrm{F}_{\mathrm{R}}\left(\frac{\mathrm{r}-2}{\mathrm{c}-3 / \mathrm{r}}\right) \text {. }
$$

Аналіз останнього виразу показує що при збільшенні числа (c) внутрішньогрупових вимірювань роль критеріальних F-статистик $\mathrm{F}_{\mathrm{G}}$ та $\mathrm{F}_{\mathrm{W}}$, відповідальних за великомасштабну адитивну і мультиплікативну нелінійності - зменшується. Головну роль починає грати нова F-статистика $\mathrm{F}_{\mathrm{R}}$, що відповідає за нелінійність дрібномасштабними, і незалежна від обсягів вибірок (r) i (c).

Рішення про те, що гіпотеза $\mathrm{H}_{0}$ не відкидається приймають, якщо статистика (13) або (14) менше $\alpha$-відсоткової точки центрального F-розподілу с (rc - 3) та rc (п-1) ступенями свободи, тобто якщо

$$
\mathrm{F}_{(\mathrm{rc}-3) ; \mathrm{rc}(\mathrm{n}-1)}^{(0)}<\mathrm{F}_{(\mathrm{rc}-\mathrm{p}) ; \mathrm{rc}(\mathrm{n}-1) ; \alpha} .
$$

На рис. 6 наведені результати обчислення комплексної критеріальної статистики $\mathrm{F}^{(0)}$ за виразом (14) для даних БІМ-сигналу (рис.4) та критичне значення F-статистики для рівнів значущості $\alpha=0,05$ та $\alpha=0,01$. Аналіз динаміки поведінки статистики $\mathrm{F}^{(0)}$ показує однозначність в прийнятті рішень $\gamma 0$ або $\gamma 1$ (прийняття гіпотез $\mathrm{H}_{0}$ i $\mathrm{H}_{1}$ відповідно) для всього інтервалу спостереження, в процесі активного моніторінгу, медико-біологічних параметрів. 


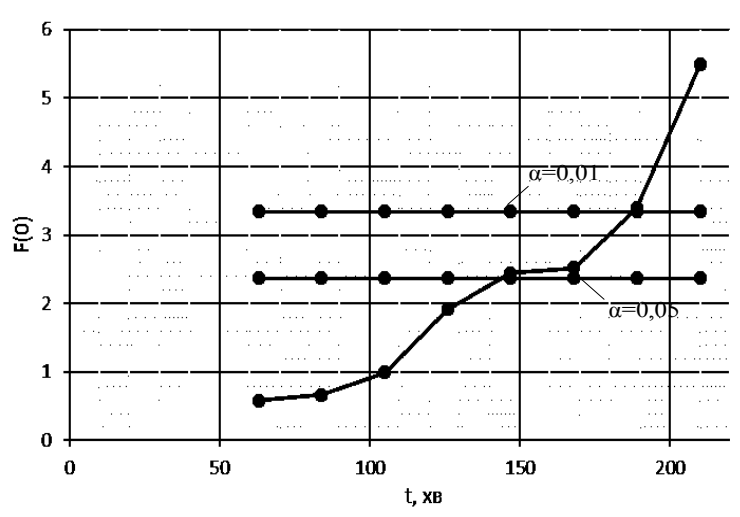

Рис. 6. Результати аналізу БІМ-сигналу модифікованим коваріаційним методом під час стандартної процедури УФ (статистика $\mathrm{F}^{(0)}$ ) та ії критичне значення для рівнів значущості $\alpha=0,05$ та $\alpha=0,01$

Варіювання рівню значущості (у визначеному метрологічними стандартами діапазоні) дозволяє регулювати чутливість інформативного параметра (статистики $\mathrm{F}^{(0}$ ) та враховувати ступінь факторного впливу на організм пацієнта під час процедури ультрафільтрації.

\section{Статистичне управління процесом ультрафільтрації за результатами активного моніторингу}

Використання модифікованого коваріаційного методу аналізу результатів активного моніторингу дає досліднику великий арсенал інформативних показників, як незалежних так і комбінованих. Як показує практика, використання будь-яких, навіть найбільш інформативних, медико-біологічних параметрів не виключає ризику в прийнятті помилкових рішень. Активний моніторинг параметрів, побічно відображають динаміку процесу ультрафільтрації, характеризується додаткової невизначеністю прийняття рішень, оскільки включає до складу контрольованих параметрів час спостереження. Останнє перетворює параметри контролю в випадкові величини, що залежать від часу, тобто в випадкові апріорі нестаціонарні процеси. Моніторинг таких процесів неминуче пов'язаний 3 прийняттям рішення $\gamma_{1}$, що відображає появу порушення динамічних властивостей медико-біологічного параметра. Використання методу оптимізації за середнім ризиком, що наведена у [17] дозволяє розрахувати кількість інформативних параметрів m діагностичної моделі, що забезпечує максимум достовірності прийнятого глобального рішення. У табл. 3 наведені результати тестування (у формі підтвердження (0) або відкидання (1) гіпотези $\mathrm{H}_{0}$ ) по статистикам $\mathrm{F}_{0}$ и $\mathrm{F}_{\mathrm{WG}}$ для рівня значущості $\alpha=0,01$. Загальна кількість використовуваних статистик $\mathrm{m}=4$, згідно з результатами оптимізації. У цій же таблиці представлено глобальні рішення $\Gamma_{0}$ чи $\Gamma_{1}$.

Таблиця 3

Результати комплексного тестування трендових змін БІМ-сигналів

\begin{tabular}{|c|c|c|c|c|c|c|c|c|c|}
\hline \multirow{2}{*}{\multicolumn{2}{|c|}{ Процедура тестування }} & \multicolumn{8}{|c|}{ Верхня межа інтервалу спостереження, хв } \\
\hline & & 62 & 83 & 103 & 124 & 145 & 166 & 187 & 210 \\
\hline \multirow{2}{*}{ сканування } & $\mathrm{F}_{0}$ & $\gamma_{0}$ & $\gamma_{0}$ & $\gamma_{0}$ & $\gamma_{0}$ & $\gamma_{0}$ & $\gamma_{0}$ & $\gamma_{0}$ & $\gamma_{1}$ \\
\hline & $\mathrm{F}_{\mathrm{WG}}$ & $\gamma_{0}$ & $\gamma_{0}$ & $\gamma_{0}$ & $\gamma_{0}$ & $\gamma_{0}$ & $\gamma_{0}$ & $\gamma_{0}$ & $\gamma_{0}$ \\
\hline \multirow{2}{*}{ накопичення } & $\mathrm{F}_{0}$ & $\gamma_{0}$ & $\gamma_{0}$ & $\gamma_{0}$ & $\gamma_{0}$ & $\gamma_{1}$ & $\gamma_{1}$ & $\gamma_{1}$ & $\gamma_{1}$ \\
\hline & $\mathrm{F}_{\mathrm{WG}}$ & $\gamma_{0}$ & $\gamma_{0}$ & $\gamma_{0}$ & $\gamma_{0}$ & $\gamma_{1}$ & $\gamma_{1}$ & $\gamma_{0}$ & $\gamma_{0}$ \\
\hline \multicolumn{2}{|c|}{ глобальне рішення } & $\Gamma_{0}$ & $\Gamma_{0}$ & $\Gamma_{0}$ & $\Gamma_{0}$ & $\Gamma_{1}$ & $\Gamma_{1}$ & $\Gamma_{1}$ & $\Gamma_{1}$ \\
\hline
\end{tabular}

Табл. 3 наочно ілюструє можливості статистичного управління процедурою ультрафільтрації при виявленні трендових змін БІМ-сигналів, які свідчать про перехід біологічного об'єкта в критичний режим, що вимагає припинення процедури ультрафільтрації.

\section{Висновки}

В результаті роботи було запропоновано здійснювати процедуру УФ з контролем стану біологічного об'єкта (пацієнта) за допомогою вимірювання і аналізу БІМ-сигналу. Для аналізу даних вимірювань був використаний класичний і модифікований коваріаційний аналіз, який відрізняється більшою інформаційної значимістю за рахунок зменшення суми випадкового залишку в дисперійному розкладанні (14) і дозволяє враховувати трендові зміни БІМсигналів на різних частотах. Розроблений метод був апробований на результатах вимірювань БІМсигналу при процедурі УФ, і показав свою працездатність для ідентифікації переходу рівня гідратації пацієнта в критичний стан (збіднення судинного русла) за допомогою статистики F0. В силу незалежності статистик, отриманих в результаті ковариационного аналізу, особливий інтерес представляє дослідження можливості їх окремого або комплексного застосування для інформаційної підтримки процедури УФ при програмному гемодіалізі.

\section{Список літератури}

1. Даугирдас Джсон Т. Руководство по диализу / Даугирдас Джсн Т. , Блейк Питер Дю., Тодд С. Инг. - М.: Центр Диализа. - 2003. - 744c.

2. Стеиюк Е.A. Основы гемодиализа / Е.А. Стеиюк. М.: Изд. дом ГЭОТАР-МЕД, 2001. - 392 c

3. Ronco C. Hemodialysis: from basic research to clinical trials / Claudio Ronco, Dinna N.Cruz. // Karger Medical \& Scientific Publishers. - 2008. - P. 277.

4. Rose B.D. Clinical physiology of acid-base and electrolyte disorders / B.D. Rose, T.W. // Medical Pub. Division. - New York.: McGraw-Hill, 2001.

5. Castellano S. Clinical, analytical and bioimpedance characteristics of persistently overhydrated haemodialysis 
patients / Sandra Castellano, Inés Palomares, Manuel Molina and et. // Nefrologia. - 2014. - № 34(6). P. 716 - 723

6. Hyponatremia, hypernatremia, and mortality in patients with chronic kidney disease with and without congestive heart failure / C.P. Kovesdy, E.H. Lott, J.L. et al. // Circulation. - 2012. - № 125. - P. $677-684$.

7. Spiegel D.M. Bioimpedance resistance ratios for the evaluation of dry weight in hemodialysis / D.M. Spiegel, K. Bashir, B. Fisch // Clin Nephrol. - 2000. № 53. - P. 108 - 114.

8. Биоимпедансный анализ состава тела человека / [Николаев Д.В., Смирнов А.В., Бобринская И.Г., Руднев С.Г.]. - М. : Наука, 2009. - 392 с.

9. Gravimetric Method for in Vitro Calibration of Skin Hydration Measurements / O.G. Martinsen, G. Orjan S. Grimnes. - Biomedical Eng., IEEE Trans. - 2008. - P. 728 - 732.

10. Lindsay R.M. Online monitoring and feedbackcontrol / R.M. Lindsay, D. Schneditz // Replacement of renal function by dialysis. - Kluwer. - 2004. - P. 555-584.

11. Jaffrin M.Y. Body fluid volumes measurements by impedance: A review of bioimpedance spectroscopy (BIS) and bioimpedance analysis (BIA) methods // M.Y. Jaffrin H. Morel - -Med Eng Phys. - 2008 Dec. - № 30(10). - P. 1257 - 1269.

12. Trevor Hastie. Generalized additive models for medical research / Trevor Hastie, Robert Tibshirani. - Stat Methods Med Res, 1995. pp. 187-196.

13. Статистика / Роберт А. Доннелли-мл. - М.: Астрель:АCT, 2007. - XIV, 367.
14. Джонсон Н. Статистика и планирование эксперимента/ Джсонсн Н., Лион Ф. - М.: Мир, 1981. - 520 c.

15. Final Draft Post-Refereeing: Taroni F., Biedermann A., Bozza S. 2016, Statistical hypothesis testing and common misinterpretations: Should we abandon p-value in forensic science applications?, Forensic Science Int., 259, e32-e36.

16. Hopkins W.G. Progressive Statistics for Studies in Sports Medicine and Exercise Science / Hopkins W.G., Marshall S.W., Batterham A.M., Hanin J. - Jan 2009, 41(1): - pp. 3-13. DOI:10.1249/MSS.0b013e31818cb278.

17. Bioimpedance Monitoring of Dialysis Patients During Ultrafiltration. / Mosiychuk V.S., Timosenko G.V., Sharpan O.B., Tkachuk B.V., Tomashevskyi R.S. // Conf. Proc., IEEE Elnano. - April 19-21, 2016. - Kyiv. -pp. 236-239

18. Уточнение электрической схемы организма для биоимпедансометрии при ультрафильтрации эквивалентной / Б.В. Ткачук, Р.С. Томачевский, Е.И. Сокол, В.Н. Лесовой // Вестник НТУ «ХПИ». - №46 (1155). - с. 56-62.

19. Актуальні проблеми автоматики та приладобудування: матеріали всеукраїнської НТК / С.І. Сокол (голова оргком.) - Х.: ТОВ «В справі», 2015. - 211 с.

Надійшла до редколегії 21.11.2017

Рецензент: д-р техн. наук, проф. О.І. Тимочко, Харківський національний університет Повітряних Сил імені Івана Кожедуба, Харків.

\section{ИНФОРМАЦИОННАЯ ТЕХНОЛОГИЯ СТАТИСТИЧЕСКОГО УПРАВЛЕНИЯ ПРОЦЕДУРОЙ УЛЬТРАФИЛЬТРАЦИИ ПРИ ПРОГРАММНОМ ГЕМОДИАЛИЗЕ}

П.Ф. Щапов, Р.С. Томашевский, Б.В. Ткачук, В.Н. Павлюк

В статье предложена информационная технология статистического управления процедурой ультрафильтрации при программном гемодиализе на основе информации, полученной из сигналов биоимпедансометрии. В статье проведен анализ литературных источников, который показал острую необходимость разработки системы информационной поддержки процедуры гемодиализа или ее автоматизации. Несовершенство классических методов оценки уровня гидратации пациента не позволят использовать их в качестве сигналов индикачии состояния биологического объекта в режиме реального времени. Аналитический обзор показал, что наиболее подходящим сигналом, с помощью которого возможен мониторинг состояния пациента, является сигнал биоимпедансометрии. Целью работы была разработка информачионной технологии мониторинга состояния пачиента и статистического управления прочедурой ультрафильтрацчии на основе сигналов биоимпедансометрии. Для анализа таких сигналов был выбран ковариачионный анализ, так как он позволяет оценить глобальные и локальные тренды сигнала с учетом его нестационарности, а также оценить значимость изменения этих трендов. На основании классического ковариачионного разложения в работе был предложен модифицированный ковариационный метод анализа, который позволяет учитывать относительное изменение трендов биоимпедансных сигналов на нескольких частотах, и, тем самым, уменьшая сумму случайного остатка. Такой подход позволяет, увеличивая чувствительность метода к динамическим изменениям, получить дополнительный информативный параметр. Экспериментальные исследования на пациентах, находящихся на процедуре программного гемодиализа, показал эффективность предложенного метода. Адекватность полученных статистических решений полностью подтвердилась результатами контрольного исследования - измерения уровня гематокрита.

Ключевые слова: программный гемодиализ, ультрафильтрация, интерстициальная жидкость, биоимпедансометрия, модель Фрикке-Морзе, ковариационный анализ, оптимизация, средний риск, статистическое управление

\section{INFORMATION TECHNOLOGY OF STATISTICAL CONTROL OF ULTRAFILTRATION PROCEDURE DURING PROGRAM HEMODIALYSIS}

P.F. Shapov, R.S. Tomashevskyi, B.V. Tkachuk, V.M. Pavlyuk

The information technology of statistical control of the procedure of ultrafiltration in program hemodialysis based on information obtained from bioimpedanceometry signals is proposed in the article. The analysis of the literature sources showed the urgent need to develop a system of informational support for the procedure of hemodialysis or its automation. Imperfection of the classical methods of assessing the level of hydration of the patient does not allow using them as signals indicating the state of the biological object in real time. The analytical review showed that the most suitable signal by which the patient's condition can be monitored is the bioimpedanceometry signal. The aim of the work was the development of information technology for monitoring the patient's condition and statistical management of the ultrafiltration procedure based on bioimpedanceometry signals. To analyze such signals, covariance analysis was chosen, since it allows estimating global and local signal trends taking into account its nonstationarity, as well as assessing the significance of changing these trends. In the work, based on the classical covariance decomposition, a modified covariance method of analysis was proposed. This method allows to take into account the relative change of bioimpedance signals trends at several frequencies, and, thereby, reducing the sum of the random remaining residue. This approach allows obtaining an additional informative parameter by increasing the sensitivity of the method to dynamic changes. Experimental studies on patients undergoing programmed hemodialysis showed the effectiveness of the proposed method. The adequacy of the statistical solutions obtained was fully confirmed by the results of a control study-measurement of the hematocrit level.

Keywords: program hemodialysis, ultrafiltration, interstitial fluid, bioimpedanceometry, Fricke-Morse model, covariance analysis, optimization, average risk, statistical control. 